\title{
Follicle stimulating hormone secreting pituitary adenoma: a challenging diagnosis
}

\author{
Madhuri Alap Mehendale*, Nidhi Devendra Kalkal, \\ Meenal Shailesh Sarmalkar, Arun Harishchandre Nayak
}

Department of Obstetrics \& Gynecology, Lokmanya Tilak Municipal Medical College and Sion Hospital, Mumbai400022, Maharashtra, India

Received: 17 January 2015

Accepted: 16 February 2015

\section{*Correspondence:}

Dr. Madhuri Alap Mehendale,

E-mail: drmadhuri1982@yahoo.co.in

Copyright: () the author(s), publisher and licensee Medip Academy. This is an open-access article distributed under the terms of the Creative Commons Attribution Non-Commercial License, which permits unrestricted non-commercial use, distribution, and reproduction in any medium, provided the original work is properly cited.

\begin{abstract}
FSH secreting pituitary adenomas are relatively uncommon brain tumours and usually non-functioning. But in rare cases they produce ovarian hyperstimulation. We report a case of a 32 year old female P2L2, with amenorrhoea of 1 year, pain in abdomen and galactorrhoea since 6 months. Initially thought to be a simple prolactinoma with multicystic ovaries, but after thorough investigations to our surprise diagnosed to be a rare case of gonadotropin secreting pituitary adenoma. Patient was successfully managed by excision of the pituitary adenoma.
\end{abstract}

Keywords: Pituitary adenoma, FSHoma, Mixed pituitary tumour, OHSS, FSH (Follicle stimulating hormone), Estradiol, LH (Luteinizing hormone)

\section{INTRODUCTION}

Pituitary adenomas are the third most common intracranial tumours and about $10 \%-17 \%$ of primary brain neoplasms are due to these tumors. ${ }^{1}$ Almost all pituitary adenomas are non-functioning tumours (40\%), prolactinomas $(30 \%)$, or growth hormone-secreting adenomas (20\%). Gonadotroph cell adenomas account for approximately $80 \%$ of non-functioning pituitary adenomas and $40 \%$ of all clinically recognized macroadenomas. ${ }^{2,3}$

Conversely, the characteristics of FSHoma in reproductive-aged women are enlarged ovaries with multiple cysts, elevated serum estradiol (E2) levels, normal to mildly elevated FSH levels, suppressed Luteinizing Hormone (LH) levels and causally induced menstrual disorder, infertility and ovarian hyperstimulation. ${ }^{2,4}$ The mechanism by which normal to mildly elevated levels of FSH induce ovarian hyperstimulation is not fully known. Kajitani et al. have hypothesized that the bioactivity of the FSH secreted by FSHoma is more active but were unable to prove this. ${ }^{5}$

Pituitary adenomas have been identified with increasing frequency in the last two decades. Follicle-Stimulating Hormone (FSH) - secreting pituitary adenoma is usually a non-functioning tumour, but in rare cases it may develop into ovarian hyperstimulation. Women with intact gonadotrope adenomas and supra-normal FSH levels are generally not recognized as exhibiting a syndrome, because many are over 45 years of age with ovaries devoid of pre-antral follicles, and are insensitive to the action of FSH. ${ }^{6}$ These gonadotrope adenomas are, therefore, more difficult to diagnose in women who are perimenopausal or postmenopausal. ${ }^{7}$ Therefore, intracranial mass effects such as visual-field defects, 
headache, and cranial nerve palsy preface the detection of FSHoma.

There have been few reports worldwide that have revealed that serum FSH levels were normal to slightly high in patients with combined FSH - secreting pituitary adenoma with ovarian hyperstimulation. This finding is different from iatrogenic ovarian hyperstimulation syndrome (OHSS) in which extremely high levels of FSH are found. Thus, an alternate explanation may exist for ovarian hyperstimulation in patients with FSHoma. We have recently treated a case of FSHoma in reproductive age.

Review of the literature revealed several interesting points about the disease:

- Normal to moderately high levels of FSH may be enough to elicit abundant follicles and subsequent multicystic ovaries.

- There is wide individual variability of E2 levels (normal to extremely high) in spite of ovarian hyperstimulation.

- Decreased LH levels cannot be explained by negative feedback of increased E2 levels or by a compression of normal hypophysis.

- FSHoma rarely causes massive ascites and thromboembolism, which are typical symptoms of ovarian hyperstimulation syndrome (OHSS).

\section{CASE REPORT}

A 32 year old female married since 14 years P2L2 (last child birth 11 year back) came to OPD with chief complaints of amenorrhoea and pain in abdomen since 1 year, weight gain since 4 months and galactorrhoea since 2 months. No history of headache, blurring of vision, vomiting. On examination, she was preobese (ht. - 155 cm, wt. - $70 \mathrm{~kg}$, BMI - 27, abdominal girth - $98 \mathrm{~cm}$ ), galactorrhoea was present, thyroid not enlarged. Abdomen was soft, non-tender and vaginal examination revealed a normal sized uterus with bilateral adnexal large cystic structures. Ultrasound performed 6 months back by a general practitioner was suggestive of bilateral multicystic ovaries with right ovary measuring $8 \times 7 \mathrm{~cm}$ and left ovary about $8.5 \times 5 \mathrm{~cm}$, for which specialist consultation was advised.

After detailed history and examination, patient was investigated.

USG showed bilateral enlarged ovaries with multiple cysts [Right ovary - 10x8x6 cm (volume - $240 \mathrm{cc}$ ), Left ovary - 10x5x6 cm (volume - $160 \mathrm{cc}$ )]. CT scan of pelvis confirmed the findings of USG.

Hormonal profile: serum prolactin - $80 \mathrm{ng} / \mathrm{ml}$ (5-26), serum AMH $<0.3 \mathrm{ng} / \mathrm{ml}$ (0.9-9.5), Serum FSH - 14 milliIU/ml (1.5- 10), Serum LH - 0.09 milliIU/ml (1.7-
15), Serum estradiol - $250 \mathrm{pg} / \mathrm{ml}$ (20-155), Thyroid profile - WNL.

Serial scan after 1 month revealed increase in size of both ovaries, Right ovary - 12x8x8 cm (400 cc), Left ovary $10 \times 7 \times 6 \mathrm{~cm}$ (volume - $220 \mathrm{cc}$ ).

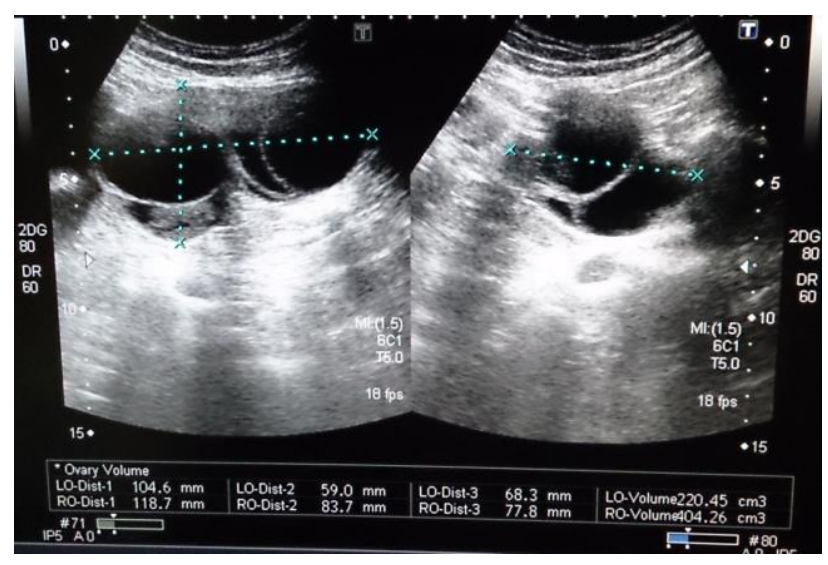

Figure 1: Ultrasound of patient showing bilateral multicystic ovaries.

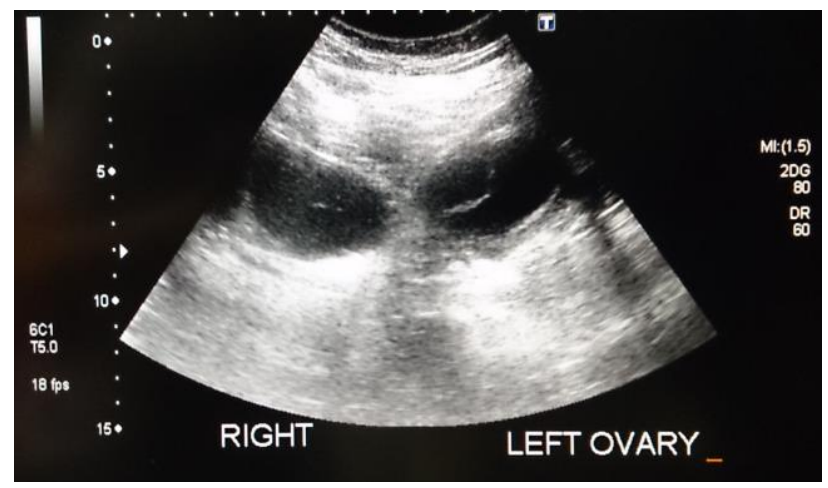

Figure 2: Ultrasound of patient showing ovaries so enlarged, seen as 'kissing ovaries' in POD.

Though prolactin levels were high, the patient had no compressive symptoms of a pituitary tumour viz. headache, vomiting, reduced vision. X-ray skull was done to look for a pituitary tumour which was suggestive of pituitary mass.

MRI brain - 3×3 $22 \mathrm{~cm}$ pituitary macroadenoma.

Perimetry - Left eye - Siebel's Scotia.

Right eye - unreliable.

To determine sure nature of pituitary tumour, other pituitary hormonal assays were done - Serum ACTH - 38 $\mathrm{pg} / \mathrm{ml}$ (0-46), Serum cortisol - $1.3 \mathrm{mcg} / \mathrm{ml} \mathrm{(3-16).} \mathrm{It}$ confirmed the nature of tumour as 'mixed pituitary adenoma' secreting FSH and prolactin. 


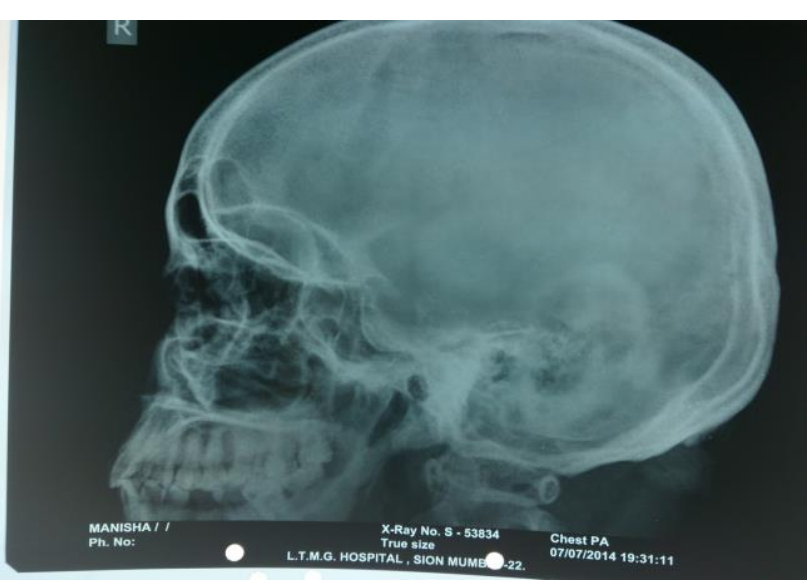

Figure 3: X-ray skull of patient showing enlarged pituitary fossa (Sella turcica) both vertically and anterioposteriorly and erosion of clivus suggestive of pituitary mass.

Trans-sphenoidal resection of tumour was performed by neurosurgeons at our hospital. Postoperatively, patient developed diabetes insipidus for 15-20 days which was managed conservatively and patient recovered gradually.

One month later patient's investigations revealed - Serum prolactin - $8.2 \mathrm{ng} / \mathrm{ml}$ (5-26), Serum FSH - 6 milliIU/ml (1.5-10), Serum LH - $8 \mathrm{milliIU} / \mathrm{ml}$ (1.7-15), Serum estradiol - $120 \mathrm{pg} / \mathrm{ml}$ (20-155). USG showed decrease in ovarian volume Right ovary - 30 cc, Left ovary - 80 cc.

Patient had her menses on day 42 of surgery. Patient is regularly following up on OPD basis and at present is symptom free.

\section{DISCUSSION}

A few cases of FSH-secreting gonadotroph cell adenoma manifesting as ovarian hyperstimulation have been reported with the endocrinological characteristics, but the true incidence of this condition including unnoticed or subclinical cases remains unclear., ${ }^{2,8}$ Age is the most fundamental characteristic for the diagnosis of this entity, because the response of the ovary to FSH stimuli is important for the onset of ovarian hyperstimulation. In postmenopausal women, FSH over secretion cannot be recognized unless a very low LH level is noticed, so that all reported patients with ovarian hyperstimulation are of reproductive age. ${ }^{9}$ Although several $\mathrm{FSH}$ receptor mutations have been identified for very rare cases of spontaneous ovarian hyperstimulation, no pathological abnormalities have been identified in the ovary in most cases of ovarian hyperstimulation caused by FSHsecreting gonadotroph cell adenoma. ${ }^{10,11}$ Therefore, regression of the ovarian hyperstimulation can be achieved by resolving the inappropriate FSH secretion in such cases.

Endocrinological pattern is also an important characteristic in the diagnosis of this entity. Serum estradiol level is elevated in response to FSH stimulation, which is secreted in adenoma cells. Subsequently, the hypothalamus-anterior pituitary gland axis is suppressed due to the negative feedback mechanism. As a result, the excessive FSH level is reduced to the normal range. Serum LH level is also significantly reduced to below the lower limit of the normal range, probably due to the negative feedback mechanism or compression of the normal pituitary gland by the tumor. ${ }^{4,8,12}$ Apparent normal FSH, suppressed LH, and high estradiol levels can be considered as the characteristic endocrinological profile of this FSH-secreting gonadotroph cell adenoma. Serum prolactin concentration was elevated in most cases, probably due to pituitary stalk compression by the sellar tumor, the so-called stalk effect. ${ }^{13}$ This observation is considered to be a non-specific finding with large pituitary adenomas.

The management being resection of pituitary tumour and follow up. After resection of a pituitary adenoma, patients need to be monitored annually with MRI, looking for evidence of a possible recurrence. Patients should also undergo hormonal testing 3 months after surgery to assess whether hypo-pituitarism is present. If there is deficiency of any of the pituitary hormones, hormonal replacement therapy should be initiated.

On several occasions, ovarian hyperstimulation is secondary to infertility treatment with gonadotropins but there are several differences between iatrogenic ovarian hyperstimulation syndrome and ovarian hyperstimulation caused by FSH-secreting gonadotroph cell adenoma. ${ }^{14,15}$ The most significant clinical difference is the change of vascular permeability. Iatrogenic ovarian hyperstimulation syndrome is generally characterized by a systemic increase of vascular permeability, manifesting as extravasation of fluid into the peritoneal cavity or third space, which does not occur in pituitary adenomainduced ovarian hyperstimulation. ${ }^{16}$ The correct diagnosis is difficult to establish based only on history of iatrogenic ovarian stimulation and the ovarian enlargement without systemic changes. The present case had multiple ovarian cysts but no ascites.

The clinical severity of ovarian hyperstimulation varies greatly, because the biological activity of FSH is not always uniform. Our case luckily had pain in abdomen due to enlarged ovaries before optic chiasma compression could occur and thus early diagnosis and proper treatment could be instituted promptly.

OHSS can occur in association with other disease states. Patients with polycystic ovary syndrome who become pregnant are at risk of OHSS as they have multiple partially stimulated antral follicles, which can overrespond to exogenous gonadotropins as reported during assisted reproductive treatment. OHSS has also been reported in association with primary hypothyroidism, possibly caused by TSH-mediated stimulation of the FSH receptor or by enhanced TRH production stimulating gonadotropin release. In addition, a single patient with 
bilateral granulosa cell tumours has been reported to have developed OHSS. ${ }^{17}$

\section{CONCLUSIONS}

The present case of FSH-secreting gonadotroph cell adenoma was the cause of ovarian cysts. We emphasize the importance of pituitary imaging and detailed endocrinological examinations as well as careful evaluation of the gynecological history in women of reproductive age to avoid unnecessary ovarian surgery.

\section{ACKNOWLEDGEMENTS}

We would like to thank neurosurgery department, LTMGH (Sion hospital), Mumbai - who performed transsphenoidal surgery to excise pituitary adenoma. We would like to thank radiology department, LTMGH (Sion hospital), Mumbai.

Funding: No funding sources Conflict of interest: None declared

Ethical approval: Not required

\section{REFERENCES}

1. Beshay VE, Beshay JE, Halvorson LM. Pituitary tumors: diagnosis, management, and implications for reproduction. Semin Reprod Med. 2007;25(5):388401.

2. Christin-Maitre S, Rongieres-Bertrand C, Kottler ML, Lahlou N, Frydman R, Touraine P, et al. A spontaneous and severe hyperstimulation of the ovaries revealing a gonadotroph adenoma. J Clin Endocrinol Metab. 1998;83:3450-3.

3. Snyder PJ. Gonadotroph cell adenomas of the pituitary. Endocr Rev. 1985;6:552-563.

4. Djerassi A, Coutifaris G, West VA, Asa SL, Kapoor SC, Pavlou SN, et al. Gonadotroph adenoma in a premenopausal woman secreting follicle-stimulating hormone and causing ovarian hyperstimulation. J Clin Endocrinol Metab. 1995;80(2):591-4.

5. Kajitani T, Liu S, Maruyama T, Uchida H, Sakurai $\mathrm{R}$, Masuda $\mathrm{H}$, et al. Analysis of serum FSH bioactivity in a patient with an FSH-secreting pituitary microadenoma and multicystic ovaries: a case report. Hum Reprod. 2008;23(2):435-9.

6. Pentz-Vidovic I, Skorić T, Grubisić G, Korsíc M, Ivicevic-Bakulic T, Besenski N, et al. Evolution of clinical symptoms in a young woman with a recurrent gonadotroph adenoma causing ovarian hyperstimulation. Eur J Endocrinol. 2000;143:60714.

7. Chaidarun SS, Klibanski A. Gonadotropinomas. Semin Reprod Med. 2002;20:339-48.
8. Shimon I, Rubinek T, Bar-Hava I, Nass D, Hadani M, Amsterdam A, et al. Ovarian hyperstimulation without elevated serum estradiol associated with pure follicle-stimulating hormone-secreting pituitary adenoma. J Clin Endocrinol Metab. 2001;86:363540.

9. Wide L, Lundberg PO. Hypersecretion of an abnormal form of follicle-stimulating hormone associated with suppressed luteinizing hormone secretion in a woman with a pituitary adenoma. $\mathbf{J}$ Clin Endocrinol Metab. 1981;53:923-30.

10. Binder H, Dittrich R, Hager I, Müller A, Oeser S, Beckmann MW, et al. Association of FSH receptor and CYP19A1 gene variations with sterility and ovarian hyperstimulation syndrome. Reproduction. 2008;135:107-16.

11. Smits G, Olatunbosun O, Delbaere A, Pierson R, Vassart G, Costagliola S. Ovarian hyperstimulation syndrome due to a mutation in the folliclestimulating hormone receptor. $N$ Engl $J$ Med. 2003;349:760-6.

12. Kihara M, Sugita T, Nagai Y, Saeki N, Tatsuno I, Seki K. Ovarian hyperstimulation caused by gonadotroph cell adenoma: a case report and review of the literature. Gynecol Endocrinol. 2006;22:110-3.

13. Karavitaki N, Thanabalasingham G, Shore HC, Trifanescu R, Ansorge O, Meston N, et al. Do the limits of serum prolactin in disconnection hyperprolactinaemia need re-definition? A study of 226 patients with histologically verified nonfunctioning pituitary macroadenoma. J Clin Endocrinol (Oxf). 2006;65:524-9.

14. Ben-Rafael Z, Strauss JF III, Mastroianni L, Flickinger GL. Differences in ovarian stimulation in human menopausal gonadotropin treated women may be related to follicle stimulating hormone accumulation. Fertil Steril. 1986;46:586-92.

15. Stone BA, Serafini PC, Quinn K, Quinn P, Kerin JF, Marrs RP. Gonadotropin and estradiol levels during ovarian stimulation in women treated with leuprolide acetate. Obstet Gynecol. 1989;73:990-5.

16. Macchia E, Simoncini T, Raffaelli V, Lombardi M, Iannelli A, Martino E. A functioning FSH-secreting pituitary macroadenoma causing an ovarian hyperstimulation syndrome with multiple cysts resected and relapsed after leuprolide in a reproductive-aged woman. Gynecol Endocrinol. 2012;28:56-9.

17. Segal R, DePetrillo AD, Thomas G. Clinical review of adult granulosa cell tumors of the ovary. Gynecol Oncol. 1995;56:338-44.

DOI: $10.5455 / 2320-1770$. ijrcog20150444

Cite this article as: Mehendale MA, Kalkal ND, Sarmalkar MS, Nayak AH. Follicle stimulating hormone secreting pituitary adenoma: a challenging diagnosis. Int J Reprod Contracept Obstet Gynecol 2015;4:493-6. 